\title{
Nitrogen Use Efficiency of Low Land Rice as Affected by Organic and Chemical Sources
}

\author{
Amina Khatun ${ }^{1 *}$, Hasina Sultana ${ }^{1}$, Md. Sultan Uddin Bhuiya ${ }^{2}$, Md. Abu Saleque ${ }^{3}$ \\ ${ }^{1}$ Rice Farming Systems Division, Bangladesh Rice Research Institute, Gazipur, Bangladesh \\ ${ }^{2}$ Department of Agronomy, Bangladesh Agricultural University, Mymensingh, Bangaladesh \\ ${ }^{3}$ Advanced Studies \& Research, Bangladesh Rice Research Institute, Gazipur, Bangladesh \\ Email: ${ }^{*}$ aminabrri@gmail.com
}

Received 6 February 2015; accepted 21 February 2015; published 25 February 2015

Copyright (C) 2015 by authors and OALib.

This work is licensed under the Creative Commons Attribution International License (CC BY). http://creativecommons.org/licenses/by/4.0/

(c) (i) Open Access

\begin{abstract}
Given the increasing dairy and poultry industries, cowdung (CD) and poultry manure (PM) might become alternative sources of nitrogen $(\mathrm{N})$ for rice production in South Asia. A field experiment was conducted during dry season (November-April) in Gazipur, Bangladesh. The experiment aimed to evaluate $\mathrm{N}$ use efficiency (NUE) in rice under varying sources of $\mathrm{N}$ application. Six treatments-1) $\mathrm{N}$-control; 2) optimum dose of nitrogen (164 $\mathrm{kg} \mathrm{N} \mathrm{ha}^{-1}$ ) from urea; 3 ) $50 \% \mathrm{~N}$ from urea and $50 \% \mathrm{~N}$ from $C D$; 4) $50 \% \mathrm{~N}$ from urea and $50 \% \mathrm{~N}$ from $P M$; 5) $100 \% \mathrm{~N}$ from $\mathrm{CD}$; and 6 ) $100 \% \mathrm{~N}$ from PMwere compared. Two mega varieties-BRRI dhan28 and BRRI dhan29-were used as test crops. In BRRI dhan28, the urea treatment had the highest agronomic use efficiency (AUE), utilization efficiency (UE) and partial factor productivity (PFP) followed by urea + PM treatment and absolute PM treatment. In BRRI dhan29, the urea + PM treatment had the highest AUE followed by absolute urea treatment while the urea + PM treatment gave the highest UE and PFP followed by urea treatment and urea + CD treatment. The absolute PM treatment gave the highest physiological efficiency (PE) followed by absolute urea treatment in BRRI dhan28. In BRRI dhan29, the absolute PM treatment had the highest PE followed by urea treatment and urea + PM treatment. The absolute PM treatment had the highest agro physiological efficiency (APE) both in BRRI dhan28 and BRRI dhan29. Based on this finding, it is concluded that the practice of integrated use of organic and chemical fertilizer has the scope to reduce chemical fertilizer and also contribute to increasing nitrogen use efficiency.
\end{abstract}

\section{Keywords}

Rice, Cowdung, Poultry Manure, Urea, N Use Efficiency

Subject Areas: Agricultural Science

${ }^{*}$ Corresponding author.

How to cite this paper: Khatun, A., Sultana, H., Bhuiya, Md.S.U. and Saleque, Md.A. (2015) Nitrogen Use Efficiency of Low Land Rice as Affected by Organic and Chemical Sources. Open Access Library Journal, 2: e1327.

http://dx.doi.org/10.4236/oalib.1101327 


\section{Introduction}

Nitrogen is one of the most yield-limiting nutrients in rice production around the world [1], especially in tropical Asian soils and almost every farmer has to apply the costly $\mathrm{N}$ fertilizer to get a desirable yield of rice [2]. Judicious and proper use of fertilizers can markedly increase the yield and improve the quality of rice [3]. However, both excess and insufficient supply of nitrogen is harmful to the rice crop and may decrease grain yield. An adequate nitrogen supply can increase as much as $60 \%$ rice production over control [4].

Worldwide, $\mathrm{N}$ recovery efficiency for cereal production is approximately $33 \%$. For lowland rice in the tropics, recovery efficiency is $30 \%-50 \%$ of applied $\mathrm{N}$ depending on season, yield level, the rate and timing of $\mathrm{N}$ application [5] [6]. Low recovery of $\mathrm{N}$ fertilizer not only increases cost of production and but also may contribute to ground water pollution [7]. So, improved $\mathrm{N}$ fertilizer practices are needed to reduce environmental impacts and increase economic benefits of $\mathrm{N}$ fertilization.

Increasing cropping intensity with modern rice varieties has enhanced nutrient mining from the soil because nutrient removal has exceeded annual replacement, even if the national recommended fertilizer doses are applied. Moreover, farmers in Bangladesh are mainly concerned about the application of $\mathrm{N}$ fertilizer and tend to neglect $\mathrm{P}$ and $\mathrm{K}$ fertilizers for rice cultivation because their application often does not produce the yield advantages of the past [2]. Such imbalanced nutrient management practices may impair productivity of the soils of Bangladesh, which contain low levels of organic matter. In spite of balanced inputs $\mathrm{N}, \mathrm{P}$ and $\mathrm{K}$ fertilizers, yield declines in India, particularly in treatments which received no $\mathrm{P}$ and $\mathrm{K}$ as compared to treatments that received balanced fertilizers [8].

Organic manures and chemical fertilizers are both important for rice cultivation. Organic manures improve the physical condition of the soil and supply limited quantities of plant nutrients through enhanced microbial activity [9]. Fertilizers, on the other hand, contain one or more plant nutrients in concentrated readily available forms. They can be so applied as to supply the nutrients needed by plants and thereby increase crop growth and yield [9].

Sustainability in crop yield and soil health could be achieved by the application of mineral fertilizers along with organic manures. Benefits of organic manures like farm yard manure, green manures, poultry manure and vermicompost are well-known but the availability is reducing day by day. These organic manures not only are good sources of nutrients but also improve the physical structure of the soil. Apart from containing NPK, these also contain small amounts of trace elements especially boron, copper, iron, sulphur, zinc and with fair quantity of growth promoting substances. Integrated nutrient management involving both the organic and inorganic source is, imperatively, essential to realize higher yield potential.

Integrated nutrient management—-the combined use of chemical fertilizers and organic amendments—can be a measure to maintain sustainable soil productivity in tropical countries such as Bangladesh. It is well recognized that soil organic matter is an important fertility parameter, which largely determines soil quality. The average organic matter content of Bangladesh soil is about $1.0 \%$. Under tropical climates increasing organic matter to a high level is not possible [2].

Cow dung is a good source of different plant nutrients particularly NPKS and judicious application of cow dung along with inorganic nutrients might be helpful to obtain a good economic return as well as provided favorable conditions for subsequent crops [10]. The application of cowdung in rice fields may reduce the requirement of chemical fertilizers. The doses of chemical fertilizer may be reduced by $33 \%$ for both dry and wet season by using cowdung and ash in the dry season [2]. The application of cowdung and ash not only supplemented chemical fertilizers but also contributed to the apparent nutrient balance [2].

Poultry manure is an excellent source of promising organic fertilizer, which is cost effective to the farmers. Nowadays, industrialization of poultry is a vital sector of national economy in Bangladesh and byproduct of this industry, i.e., manure and poultry liter may be used as good source of organic matter with a view to develop an agronomically and economically suitable combination of organic and inorganic fertilizers for improving soil health and rice production. It has a high nutritional value for plant growth [11] [12]. Management of animal wastes from animal confinement facilities is a very important issue in swine and poultry farming. If inadequately handled, animal manure poses a significant threat to the quality of air and water nearby the storage and disposal areas. When properly managed, animal manure is a valuable source of fertilizer for crop production [13]. Under these circumstances, the present study was designed to evaluate the $\mathrm{N}$ use efficiency of rice under organic and chemical sources. 


\section{Materials and Methods}

The field experiment was conducted at the experimental farm of the Bangladesh Rice Research Institute (BRRI), Gazipur, Bangladesh, located at $23^{\circ} 59^{\prime} \mathrm{N}$ latitude, $90^{\circ} 24^{\prime} \mathrm{E}$ longitude. The site is about $35 \mathrm{~m}$ above the mean sea level and has a subtropical climate, which is strongly influenced by the southwestern monsoon. It belongs to agro-ecological zone (AEZ) number 28 known as Madhupur Tract. The average annual rainfall is $2000 \mathrm{~mm}$ with more than $80 \%$ of it occurring from mid-June to the end of September. Mean temperature is lowest $\left(15^{\circ} \mathrm{C}\right)$ in January and highest $\left(30^{\circ} \mathrm{C}\right)$ in May.

The soil of the experimental field is Chhiata clay loam, a member of the fine, hyperthermic Vertic Endoaquept [2]. The initial soil chemical properties at $0-15 \mathrm{~cm}$ soil depth were as follows: $\mathrm{pH}$ 6.1, organic matter $2.02 \%$, total $\mathrm{N}$ content $0.07 \%$, available phosphorus (P) $10.14 \mathrm{mg} \cdot \mathrm{kg}^{-1}\left(0.5 \mathrm{M} \mathrm{NaHCO}_{3}\right.$ extracted), exchangeable potassium (K) $0.17 \mathrm{meq} / 100 \mathrm{~g}$ soil (Neutral $1.0 \mathrm{~N} \mathrm{NH}_{4} \mathrm{OAc}$ extracted), available sulfur (S) $20 \mathrm{mg} \cdot \mathrm{kg}^{-1}$ $\left[\mathrm{Ca}\left(\mathrm{H}_{2} \mathrm{PO}_{4}\right)_{2}\right.$ extracted], and available zinc $(\mathrm{Zn}) 2.8 \mathrm{mg} \cdot \mathrm{kg}^{-1}(0.01 \mathrm{~N} \mathrm{HCl}$ extracted $)$.

In Bangladesh context two popular mega winter rice varieties BRRI dhan28 and BRRI dhan29 were grown in the experimental field under fully irrigated conditions during boro'2010-2011 (November-April) season. BRRI dhan28 is a short duration high yielding boro variety (growth duration 145 days) and BRRI dhan29 is a long duration high yielding boro variety (growth duration 160 days). These two varieties were transplanted in first week of January with 40 - 45 days old seedlings and harvested in May. Two/three rice seedlings were transplanted maintaining $20 \times 20 \mathrm{~cm}$ spacing. The seed rate for rice was $30 \mathrm{~kg} \cdot \mathrm{ha}^{-1}$. The experiment was conducted in a randomized complete block design with four replications. Unit plot size was $5 \times 4 \mathrm{~m}$. All plots were surrounded by soil levees $30 \mathrm{~cm}$ high to avoid $\mathrm{N}$ contamination between plots. After transplanting the seedlings, intercultural operations like weeding, irrigation and control of pest were done as and when necessary for better growth and development of rice plants. At maturity the crop was harvested manually at $15 \mathrm{~cm}$ above ground level, however, 16 hills from each plot were harvested at the ground level for measuring yield components and straw yield. The grain yield was recorded at $14 \%$ moisture content and straw yield as oven dry basis following standard procedures as described by [14]. The 16 hills were selected at random in each plot just before harvesting to estimate plant height and tiller and panicle number. The grain number panicle ${ }^{-1}$, weight of 1000 grains, harvest index and sterility (\%) were calculated by following standard procedures as described by [15].

Harvest index (HI) was computed by dividing the grain yield by the total dry matter (grain yield + straw yield) and was expressed as percentage as follows:

$$
\mathrm{HI}=\left(\frac{\text { Grain yield }}{\text { Grain yield }+ \text { Straw yield }}\right) \times 100 \text {. }
$$

Sterility was computed by dividing the number of unfilled spikelets by the total number of spikelets (filled grains + unfilled spikelets) and was expressed as percentage as follows:

$$
\text { Sterility }(\%)=\left(\int \frac{\text { Unfilled spikelets }}{\text { Unfilled spikelets }+ \text { filled grains }}\right) \times 100 .
$$

Rice plants from $5 \mathrm{~m}^{2}$ area of the middle of each plot were harvested and threshed. The grains were dried in sunlight and winnowed before weighing and yield was adjusted to $14 \%$ moisture content and was converted into $\mathrm{t} \cdot \mathrm{ha}^{-1}$. Six treatments were consisted as follows: 1$) \mathrm{N}$ control $\left(0 \mathrm{~kg} \mathrm{~N} \mathrm{ha}^{-1}\right)$, 2) Optimum dose of nitrogen (164 $\mathrm{kg} \cdot \mathrm{ha}^{-1}$ ) from urea 3) $50 \% \mathrm{~N}$ from urea and $50 \% \mathrm{~N}$ from cowdung (CD), 4) $50 \% \mathrm{~N}$ from urea and $50 \% \mathrm{~N}$ from poultry manure (PM), 5) $100 \% \mathrm{~N}$ from CD and 6) $100 \% \mathrm{~N}$ from from PM.

Nitrogen was top dressed as urea in three equal splits: 20, 35 and 50 days after transplanting (DAT) for BRRI dhan28 and 20, 35 and 55 DAT for BRRI dhan29. Phosphorus, K, S and Zn were applied as triple super phosphate, muriate of potash, gypsum and zinc sulphate, respectively, during final land preparation. The CD and PM were applied on a dry weight basis and mixed well with the soil, by manual digging, about two weeks before transplanting of rice. The CD was collected from the BRRI cattle shed and PM was collected from a nearby poultry farm. Nutrient concentrations in CD and PM were determined. The N, P, K and S concentration in CD (oven dry basis) were $0.85 \%, 0.33 \%, 0.52 \%$ and, $0.08 \%$ and those in PM were $2.28 \%, 1.03 \%, 1.20 \%$ and $0.24 \%$, respectively.

Nitrogen was determined from the collected plant samples. Grain and straw samples from each plot (200 mg) were taken and separately oven dried at $65^{\circ} \mathrm{C}$ over night to grind in a grinding machine. The ground sample was 
digested in concentrated $\mathrm{H}_{2} \mathrm{PO}_{4}$ and total $\mathrm{N}$ concentration was determined by micro Kjeldahl method [14]. Total $\mathrm{N}$ uptake was determined by the following formulae:

$$
\begin{aligned}
& \text { Nitrogen uptake by grain }\left(\mathrm{kg} \cdot \mathrm{ha}^{-1}\right)=\frac{\% \mathrm{~N} \text { in grain } \times \text { Grain yield }\left(\mathrm{kg} \cdot \mathrm{ha}^{-1}\right)}{100} \\
& \text { Nitrogen uptake by straw }\left(\mathrm{kg} \cdot \mathrm{ha}^{-1}\right)=\frac{\% \mathrm{~N} \text { in straw } \times \text { straw yield }\left(\mathrm{kg} \cdot \mathrm{ha}^{-1}\right)}{100} .
\end{aligned}
$$

Nitrogen use efficiencies were calculated using the following formulas [16]:

Agronomic efficiency $(A E)$. It is expressed as difference in grain yield between fertilized and unfertilized plot divided by the quantity of nutrient applied. It is expressed as $\mathrm{kg}^{\mathrm{kg}}{ }^{-1}$.

$$
\mathrm{AE}=\frac{\left(G_{f}-G_{u}\right)}{N_{a}}
$$

where $G_{f}$ is the grain yield of the fertilized plot $(\mathrm{kg}), G_{u}$ is the grain yield of the unfertilized plot $(\mathrm{kg})$, and $N_{a}$ is the quantity of $\mathrm{N}$ applied $(\mathrm{kg})$.

Physiological use efficiency (PE). The physiological efficiency is the difference in biological (grain + straw) yield between fertilized and unfertilized plots over difference in nutrient uptake between fertilized and unfertilized plots. It is expressed as $\mathrm{kg} \cdot \mathrm{kg}^{-1}$.

$$
\mathrm{PE}=\frac{\left(Y_{f}-Y_{u}\right)}{\left(N_{t f}-N_{t u}\right)}
$$

where $Y_{f}$ is the total biological yield ( grain plus straw) of the fertilized plot (kg), $Y_{u}$ is the total biological yield of the unfertilized plot (kg), $N_{t f}$ is the nutrient accumulation of the fertilized plot $(\mathrm{kg})$, and $N_{t u}$ is the nutrient accumulation of the unfertilized plot (kg).

Agrophysiological efficiency (APE). The difference in grain yield between fertilized and unfertilized plots divided by the difference in nutrient uptake in them is known as agrophysiological efficiency (APE).

$$
\mathrm{APE}=\frac{\left(G_{f}-G_{u}\right)}{\left(N_{t f}-N_{t u}\right)}
$$

where $G_{f}$ is the grain yield of the fertilized plot (kg), $G_{u}$ is the grain yield of the unfertilized plot $(\mathrm{kg}), N_{t f}$ is the $\mathrm{N}$ accumulation by straw and grains in the fertilized plot $(\mathrm{kg}), N_{t u}$ is the $\mathrm{N}$ accumulation by straw and grains in the unfertilized plot (kg). The unit of agrophysiological efficiency is $\mathrm{kg}^{\mathrm{kg}}{ }^{-1}$.

Apparent recovery efficiency (ARE). It states that the percentage of the applied nutrient that is apparently absorbed the crop.

$$
\mathrm{ARE}=\frac{\left(N_{f}-N_{u}\right) \times 100}{N_{a}}
$$

where $N_{f}$ is the $\mathrm{N}$ accumulation by the total biological yield (grain plus straw) in the fertilized plot (kg), $N_{u}$ is the $\mathrm{N}$ accumulation by the total biological yield (grain plus straw) in the unfertilized plot (kg), and $N_{a}$ is the quantity of $\mathrm{N}$ applied (kg).

Utilization efficiency $(U E)$. The product of physiological efficiency and aparent recovery efficiency is known as utilization efficiency (UE). Essentially, the UE is dimensionless.

$$
\mathrm{UE}=\mathrm{PE} \times \mathrm{ARE}
$$

Partial factor productivity (PFP). The grain yield per quantity of nutrient applied, is considered as partial factor productivity (PFP). It is also unitless.

$$
\mathrm{PFP}=\frac{G_{f}}{N_{a}}
$$

Internal use efficiency of applied nitrogen (IUE). It is calculated using the following formula: 


$$
\text { IUE }=\frac{G Y}{U N} \times 100
$$

where, GY is the grain yield $\left(\mathrm{kg} \cdot \mathrm{ha}^{-1}\right)$ and $\mathrm{UN}$ is the total $\mathrm{N}$ uptake $\left(\mathrm{kg} \cdot \mathrm{ha}{ }^{-1}\right)$.

Reciprocal of Internal use efficiency (RIUE): It is the reverse calculation of IUE.

Analysis of variance (ANOVA) of the measured parameters was performed and the treatment means were compared using Least Significant Difference (LSD) at the 5\% level of probability [17]. The yield and N uptake parameters were analyzed by ordinary least squares linear regression as done by [18]. The significance test of the regression analysis was done following [19].

\section{Results and Discussion}

\subsection{Tiller Production at Maturity}

Nitrogen sources $(\mathrm{N})$ and variety $(\mathrm{V})$ interactions showed significant effect $(\mathrm{P}<0.01)$ on tiller production at maturity. The individual effects of $\mathrm{N}$ and $\mathrm{V}$ for tiller production was also significant $(\mathrm{P}<0.01)$ (Table 1$)$. The $\mathrm{N}$ control plots produced tiller number of 224 and 218 per $\mathrm{m}^{2}$ in BRRI dhan28 and BRRI dhan29. In BRRI dhan28 the absolute urea treatment increased the number of tiller to $321 \mathrm{per}^{2}$ followed by urea $+\mathrm{CD}$ treatment (313 $\mathrm{m}^{-2}$ ). The urea $+\mathrm{CD}$ treatment and urea + PM treatment gave statistically similar number of tillers. The absolute CD treatment and the absolute PM treatment produced statistically similar number of tillers. The absolute urea treatment gave significantly higher tiller in comparison to that of absolute CD treatment and absolute PM treatment. In BRRI dhan29, the absolute urea treatment gave the highest number of tillers $\left(383 \mathrm{~m}^{-2}\right)$ followed by urea + PM treatment $\left(373 \mathrm{~m}^{-2}\right)$. The absolute PM treatment and urea + CD treatment gave statistically similar number of tillers. The absolute CD treatment gave significantly lower tiller production compared to that of urea + CD treatment. Irrespective of N sources, BRRI dhan29 produced significantly higher number of tillers compared to BRRI dhan28 except $\mathrm{N}$ control and absolute CD treatment. On the other hand, the absolute CD treatment produced of 261 and 256 tillers per $\mathrm{m}^{2}$ in BRRI dhan28 and BRRI dhan29, respectively.

\subsection{Panicle Production}

Nitrogen sources $(\mathrm{N})$ and variety $(\mathrm{V})$ interactions for panicle production were significant $(\mathrm{P}<0.01)$. The individual effect of $\mathrm{N}$ for panicle production was also significant $(\mathrm{P}<0.01)$ (Table 1). In BRRI dhan28, the urea treatment gave the highest number of panicle followed by urea + CD treatment and urea + PM treatment. The absolute CD and absolute PM gave statistically similar number of panicles. The $\mathrm{N}$ control treatment gave the lowest number of panicles. All the $\mathrm{N}$ treatments produced significantly higher number of panicles in comparison to $\mathrm{N}$ control treatments. In BRRI dhan29, the urea treatment gave the highest number of panicles followed by urea + PM treatment. The urea + CD treatment, urea + PM treatment and absolute PM treatment gave statistically similar number of panicles. All the treatments produced significantly higher number of panicles in comparison to $\mathrm{N}$ control treatment as well as BRRI dhan28 (Table 1). Under urea treatment, BRRI dhan29 gave significantly higher number of panicles compared to BRRI dhan28. Under urea + CD treatment, urea + PM treatment and absolute PM treatment, BRRI dhan29 gave significantly higher number of panicles compared to BRRI dhan28. An exception was observed in $\mathrm{N}$ control treatment and absolute CD treatment. Under N control treatment, BRRI dhan28 and BRRI dhan29 produced statistically similar number of panicle production. Similarly, under absolute CD treatment, BRRI dhan28 and BRRI dhan29 gave statistically similar panicle production (Table 1).

\subsection{Grain Yield}

Interaction of nitrogen sources $(\mathrm{N})$ and variety $(\mathrm{V})$ for grain yield demonstrated insignificant $(\mathrm{P}>0.05)$ effect, however, both the variety and sources of $\mathrm{N}$, individually, produced significant effect on the rice grain yield $(\mathrm{P}<$ 0.01). BRRI dhan29 out yielded BRRI dhan 28 at all $\mathrm{N}$ treatments including the control and application of $\mathrm{N}$ through organic or inorganic sources increased grain yield dramatically in both the varieties (Table 1). In the control plots, BRRI dhan28 gave $3.80 \mathrm{t} \cdot \mathrm{ha}^{-1}$ compared to $4.53 \mathrm{t} \cdot \mathrm{ha}^{-1}$ in BRRI dhan29. The application of $\mathrm{N}$ through urea increased grain yield over the $\mathrm{N}$ control by about $2.89 \mathrm{t} \cdot \mathrm{ha}^{-1}$ in BRRI dhan28 and $3.01 \mathrm{t} \cdot \mathrm{ha}^{-1}$ in BRRI dhan29. Sharing the $\mathrm{N}$ between urea and CD decreased yield significantly in both the varieties compared 
Table 1. Tiller and panicle production and yields of two rice varieties as influenced by different nitrogen sources.

\begin{tabular}{|c|c|c|c|c|}
\hline $\begin{array}{l}\text { Nitrogen sources } \\
(\mathrm{N})\left(\mathrm{kg} \cdot \mathrm{ha}^{-1}\right)\end{array}$ & $\begin{array}{l}\text { Tiller m}^{-2} \\
\text { (No.) }\end{array}$ & $\begin{array}{l}\text { Panicle } \mathrm{m}^{-2} \\
\text { (No.) }\end{array}$ & $\begin{array}{c}\text { Grain yield } \\
\left(t \cdot h a^{-1}\right)\end{array}$ & $\begin{array}{c}\text { Straw yield } \\
\left(\mathrm{t} \cdot \mathrm{ha}^{-1}\right)\end{array}$ \\
\hline \multicolumn{5}{|c|}{ BRRI dhan28 } \\
\hline Control & 224 & 214 & 3.80 & 4.22 \\
\hline Urea & 321 & 309 & 6.69 & 6.94 \\
\hline Urea + CD & 313 & 299 & 6.07 & 6.33 \\
\hline $\mathrm{CD}$ & 261 & 250 & 4.61 & 4.85 \\
\hline Urea + PM & 301 & 286 & 6.46 & 6.52 \\
\hline $\mathrm{PM}$ & 274 & 265 & 6.46 & 6.61 \\
\hline Avg. & 282 & 271 & 5.68 & 5.91 \\
\hline \multicolumn{5}{|c|}{ BRRI dhan29 } \\
\hline Control & 218 & 209 & 4.53 & 5.02 \\
\hline Urea & 383 & 361 & 7.54 & 7.73 \\
\hline Urea + CD & 361 & 346 & 7.35 & 7.66 \\
\hline CD & 256 & 243 & 5.63 & 5.76 \\
\hline Urea + PM & 373 & 347 & 7.63 & 7.94 \\
\hline $\mathrm{PM}$ & 362 & 346 & 7.10 & 7.32 \\
\hline Avg. & 326 & 309 & 6.63 & 6.91 \\
\hline $\mathrm{LSD}_{0.05}$ for $\mathrm{N}$ & 29.27 & 28.48 & 0.25 & 0.33 \\
\hline $\mathrm{LSD}_{0.05}$ for $\mathrm{V}$ & 16.90 & 16.44 & 0.15 & 0.19 \\
\hline $\mathrm{LSD}_{0.05}$ for $\mathrm{N} \times \mathrm{V}$ & 41.40 & 40.28 & NS & NS \\
\hline CV (\%) & 9.5 & 9.7 & 4.0 & 5.0 \\
\hline
\end{tabular}

NS: non-significant at the 0.05 probability levels.

to that obtained with urea. But the urea + CD treatment gave a yield advantage of 2.27 and $2.82 \mathrm{t}^{-h^{-1}}{ }^{-1}$, compared to control, in BRRI dhan28 and BRRI dhan29, respectively. When the entire $\mathrm{N}$ was applied solely through CD, the grain yield decreased to 4.61 and $5.63 \mathrm{t}^{\cdot h a^{-1}}$ in BRRI dhan28 and BRRI dhan29, respectively. These yields were statistically lowest among the $\mathrm{N}$ treatments in both the varieties, however, significantly higher than that obtained with the inherent soil N. The urea + PM treatment gave similar yield to that of urea in both the varieties, however, BRRI dhan 29 gave about $1.17 \mathrm{t} \cdot \mathrm{ha}^{-1}$ higher yield than BRRI dhan28. The PM treatment gave similar yield to that with urea + PM in BRRI dhan28, but BRRI dhan29 gave significantly lower in PM than the urea + PM. About $0.73 \mathrm{t} \cdot \mathrm{ha}^{-1}$ yield advantage with BRRI dhan 29 compared to BRRI dhan28 explained the fact that the former variety has capacity of exploiting soil inherent $\mathrm{N}$ of about $10 \mathrm{~kg}$ more than the latter variety. Apparent $\mathrm{N}$ recovery (ANR) was higher for chemical $\mathrm{N}$ application compared to organic $\mathrm{N}$ treatments. [20] and [21] reported nitrogen availability as $30 \%$ for cow manure and $70 \%$ for PM while [22] reported it as $10 \%-25 \%$ for CM and 30\% - 50\% for PM in the fertile soil of a pot experiment. However, relatively lower ANR for manure application was observed in this study. For CM application, not only ANR but also plant dry matter weight and plant $\mathrm{N}$ accumulation were lower compared to the other treatments. Therefore, only CM application might not produce an optimal rice yield. Recently, many researchers including [23] [24] and [25] indicated that use of organic manures in conjunction with mineral fertilizer is very important for ensuring better soil health and sustaining crop productivity. Therefore, a mix application of manures with mineral $\mathrm{N}$ fertilizer might provide high inorganic $\mathrm{N}$ in soil and higher crop production. 


\subsection{Straw Yield}

The individual effect of nitrogen source $(\mathrm{N})$ for straw yield was highly significant $(\mathrm{P}<0.01)$ (Table 1$)$. In BRRI dhan28, the absolute urea treatment gave the higher straw yield $\left(6.94 \mathrm{t}^{-h} \mathrm{~h}^{-1}\right)$ followed by absolute PM treatment $\left(6.61 \mathrm{t} \cdot \mathrm{ha}^{-1}\right)$ and urea + PM treatment $\left(6.52 \mathrm{t} \cdot \mathrm{ha}^{-1}\right)$. The absolute PM treatment and absolute CD treatment gave the straw yield of $6.61 \mathrm{t} \cdot \mathrm{ha}^{-1}$ and $4.85 \mathrm{t} \cdot \mathrm{ha}^{-1}$, respectively. The absolute PM treatment gave significantly higher straw yield than that of absolute CD treatment. On the other hand, absolute urea treatment gave significantly higher straw yield $\left(6.94 \mathrm{t} \cdot h \mathrm{a}^{-1}\right)$ than that of urea $+\mathrm{CD}$ treatment $\left(6.33 \mathrm{t} \cdot \mathrm{ha}^{-1}\right)$. The urea $+\mathrm{CD}$ treatment and urea + PM treatment gave statistically similar straw yield (6.33 $\mathrm{t}^{-1} \mathrm{~h}^{-1}$ and $6.52 \mathrm{t} \cdot \mathrm{ha}^{-1}$, respectively). In BRRI dhan29, the urea + PM treatment gave higher straw yield $\left(7.94 \mathrm{t} \cdot \mathrm{ha}^{-1}\right)$ followed by urea treatment $\left(7.73 \mathrm{t} \cdot \mathrm{ha}^{-1}\right)$ and urea + CD treatment $\left(7.66 t^{t} \cdot \mathrm{ha}^{-1}\right)$. The absolute PM treatment gave significantly lower straw yield $\left(7.32 \mathrm{t}^{\mathrm{h}} \mathrm{ha}^{-1}\right)$ in comparison to urea + PM treatment $\left(7.94 \mathrm{t} \cdot \mathrm{ha}^{-1}\right)$. The absolute CD treatment gave significantly lower straw yield $\left(5.76 \mathrm{t}^{\mathrm{h} h \mathrm{~h}^{-1}}\right)$ compared to absolute PM treatment $\left(7.32 \mathrm{t} \cdot \mathrm{ha}^{-1}\right)$. On the other hand, urea $+\mathrm{CD}$ treatment gave significantly higher straw yield $\left(7.66 \mathrm{t}^{-\mathrm{ha}^{-1}}\right)$ in comparison to absolute CD treatment $\left(5.76 \mathrm{t} \cdot \mathrm{ha}^{-1}\right)$. The urea $+\mathrm{CD}$ treatment and urea + PM treatment gave statistically similar straw yield. The lowest straw yield was obtained from $\mathrm{N}$ control treatment in both the varieties (Table 1). The individual effect of variety $\mathrm{V}$ for straw yield was significant $(\mathrm{P}<0.01)$. In $\mathrm{N}$ control treatment, BRRI dhan29 gave significantly higher straw yield $\left(5.02 \mathrm{t} \cdot \mathrm{ha}^{-1}\right)$ in comparison to BRRI dhan28 (4.22 tha $\left.{ }^{-1}\right)$. In urea treatment, BRRI dhan28 and BRRI dhan29 gave the straw yield of $6.94 \mathrm{t} \cdot \mathrm{ha}^{-1}$ and $7.73 \mathrm{t} \cdot \mathrm{ha}^{-1}$, respectively. Under this treatment BRRI dhan29 gave the highest straw yield in comparison to BRRI dhan28. Under urea + CD treatment and absolute CD treatment, BRRI dhan29 gave significantly higher straw yields in comparison to BRRI dhan28. Under urea + PM treatment, BRRI dhan29 also gave significantly higher straw yield compared to BRRI dhan28. A similar trend of straw yield was also observed in absolute PM treatment.

\subsection{Grains Panicle ${ }^{-1}$}

Nitrogen sources $(\mathrm{N})$ and variety $(\mathrm{V})$ interactions were significant $(\mathrm{P}<0.05)$ for the number of grains per panicle. The individual effect of $\mathrm{N}$ for grains panicle ${ }^{-1}$ was highly significant $(\mathrm{P}<0.01)$ (Table 2). The $\mathrm{N}$ control plots produced the lowest grains per panicle in both the varieties-78 in BRRI dhan28 and 92 in BRRI dhan29. In case of BRRI dhan28, urea + CD gave the similar number of grains per panicle as obtained in the $\mathrm{N}$ control plot, but in this treatment BRRI dhan29 increased grains per panicle significantly higher than the $\mathrm{N}$ control. BRRI dhan28 increased grains per panicle in urea, CD, PM and urea + PM treatment than the $\mathrm{N}$ control plots, but the difference among urea, $\mathrm{CD}, \mathrm{PM}$ and urea + PM was not significant. The application of $\mathrm{N}$ increased grains per panicle significantly higher than that obtained in the $\mathrm{N}$ control in BRRI dhan29. Among the $\mathrm{N}$ sources, the lowest grain per panicle was found in CD treatment. Both the urea and urea + CD treatment produced significantly higher number of grains panicle ${ }^{-1}$ compared to the CD. Similarly urea + PM and PM treatment increased grains per panicle in comparison to that in urea and urea $+C D$ treatment. The difference in grains per panicle between BRRI dhan28 and BRRI dhan29 was larger in urea + CD, urea + PM and PM compared to that in urea treatment. Both the $\mathrm{N}$ control and $\mathrm{CD}$ treatment showed similar difference in grains per panicle between the two tested varieties, but the difference was larger in urea than in N control and CD treatment. In the N control and CD treatments, BRRI dhan 29 gave 14 and 13 more grain than the BRRI dhan28. In the urea treatment, the difference was 23, while in other treatments BRRI dhan29 gave 34 - 37 more grains per panicle than in BRRI dhan28.

\subsection{0-Grain Weight}

Nitrogen sources $(\mathrm{N}) \times$ variety $(\mathrm{V})$ interactions were insignificant for 1000 -grain weight $(\mathrm{P}>0.05)$. The individual effect of $\mathrm{N}$ was also insignificant $(\mathrm{P}>0.05$ ) for 1000-grain weight (Table 2). In BRRI dhan28, 1000grain weight was produced of $22 \mathrm{~g}$ in all $\mathrm{N}$ treatments. In BRRI dhan29, 1000-grain weight ranged from $22-24$ $\mathrm{g}$ among the $\mathrm{N}$ treatments. The individual effect of $(\mathrm{V})$ was significant $(\mathrm{P}<0.01)$ for 1000 -grain weight. BRRI dhan29 gave higher 1000-grain weight in comparison to BRRI dhan28 except absolute PM treatment. The absolute PM treatment gave 22 g 1000-grain weight in BRRI dhan29.

\subsection{Sterility Percentage}

In BRRI dhan28, the higher sterility (\%) was obtained from urea treatment followed by urea + CD treatment and 
Table 2. Different yield parameters of two rice varieties as influenced by different nitrogen sources.

\begin{tabular}{|c|c|c|c|c|}
\hline $\begin{array}{l}\text { Nitrogen source } \\
(\mathrm{N})\left(\mathrm{kg} \cdot \mathrm{ha}^{-1}\right)\end{array}$ & Grains panicle $^{-1}$ & 1000 grain wt (g) & Sterility (\%) & Harvest index \\
\hline \multicolumn{5}{|c|}{ BRRI dhan28 } \\
\hline Control & 78 & 22 & 6.20 & 0.44 \\
\hline Urea & 90 & 22 & 17.52 & 0.45 \\
\hline Urea + CD & 79 & 22 & 16.34 & 0.45 \\
\hline $\mathrm{CD}$ & 87 & 22 & 10.02 & 0.45 \\
\hline Urea + PM & 86 & 22 & 15.58 & 0.46 \\
\hline $\mathrm{PM}$ & 88 & 22 & 14.12 & 0.46 \\
\hline Avg. & 85 & 22 & 13.30 & 0.45 \\
\hline \multicolumn{5}{|c|}{ BRRI dhan29 } \\
\hline Control & 92 & 23 & 21.81 & 0.44 \\
\hline Urea & 113 & 24 & 18.79 & 0.46 \\
\hline Urea + CD & 113 & 24 & 21.63 & 0.45 \\
\hline CD & 100 & 24 & 25.09 & 0.46 \\
\hline Urea + PM & 123 & 24 & 18.77 & 0.45 \\
\hline PM & 123 & 22 & 17.54 & 0.46 \\
\hline Avg. & 111 & 24 & 20.61 & 0.45 \\
\hline $\mathrm{LSD}_{0.05}$ for $\mathrm{N}$ & 9.55 & NS & NS & 0.005 \\
\hline $\mathrm{LSD}_{0.05}$ for $\mathrm{V}$ & 5.51 & 0.74 & 2.02 & NS \\
\hline $\mathrm{LSD}_{0.05}$ for $\mathrm{N} \times \mathrm{V}$ & 13.50 & NS & 4.94 & NS \\
\hline CV (\%) & 9.6 & 5.6 & 20.3 & 1.2 \\
\hline
\end{tabular}

NS: non-significant at the 0.05 probability levels.

urea + PM treatment. The urea + PM treatment and absolute PM treatment gave statistically similar sterility (\%). The absolute PM treatment gave significantly higher sterility (\%) compared to absolute CD treatment. All the N treatments gave significantly higher sterility (\%) in comparison to $\mathrm{N}$ control treatment. A different scenario was observed in BRRI dhan29. In BRRI dhan29, the absolute CD treatment gave the highest sterility followed by $\mathrm{N}$ control treatment and urea + CD treatment. The urea treatment, urea + PM treatment and absolute PM treatment produced statistically similar sterility. The absolute CD treatment gave significantly higher sterility compared to absolute PM treatment. Regardless of N sources BRRI dhan29 produced higher sterility than the BRRI dhan28. Under urea + CD treatment, BRRI dhan29 gave significantly higher sterility compared to BRRI dhan28. A similar scenario was also observed in absolute CD treatment. But under urea treatment, BRRI dhan28 and BRRI dhan29 gave statistically similar sterility. Under urea + PM treatment BRRI dhan29 produced higher sterility compared to BRRI dhan28. A similar scenario was also observed in absolute PM treatment (Table 2).

\subsection{Harvest Index}

In both the tested varieties (BRRI dhan28 and BRRI dhan29) the harvest index (HI) varied from 0.44 to 0.46 . The $\mathrm{N}$ control plots gave the lowest harvest index in both the varieties. The application of $\mathrm{N}$ increased $\mathrm{HI}$ slightly. In BRRI dhan28, the urea + PM treatment and absolute PM treatment gave the higher HI followed by absolute urea treatment, urea + CD treatment and absolute CD treatment. In BRRI dhan29, the absolute urea treatment, absolute CD treatment and absolute PM treatment gave the higher HI (0.46) followed by urea + CD 
treatment and urea + PM treatment (0.45) (Table 2).

\subsection{Relationship between Dry Matter at Harvest and Grain Yield}

A relationship between dry matter at harvest and grain yield was determined in BRRI dhan28 and BRRI dhan29. Grain yield increased significantly $(\mathrm{P}<0.01)$ and quadratically with increasing dry matter in both the varieties. The quadratic regression equation $\left(Y=-0.0 x^{2}+3.1 x-7427.9\right.$ for BRRI dhan28 and $Y=0.00 x^{2}+0.90 x-706.24$ for BRRI dhan29) can explain 99\% of the relationship for BRRI dhan28 $\left(\mathrm{R}^{2}=0.99\right)$ and $98 \%$ of the relationship for BRRI dhan29 $\left(\mathrm{R}^{2}=0.98\right)$. Maximal grain yields of about $6690 \mathrm{~kg} \cdot \mathrm{ha}^{-1}$ were achieved at about $7214 \mathrm{~kg} \cdot \mathrm{ha}{ }^{-1}$ of dry matter production in BRRI dhan28, with a harvest index of about 0.46 and $7630 \mathrm{~kg} \cdot \mathrm{ha}^{-1}$ were achieved at about $7983 \mathrm{~kg} \cdot \mathrm{ha}^{-1}$ of dry matter production in BRRI dhan29, with a harvest index of about 0.46 (Figure 1). [26] reported that grain yield in cereals is related to biological yield and harvest index. The biological yield of a cereal crop is the total yield of plant tops and is an indication of the yield of the photosynthetic capability of the crop in question.

\subsection{Nitrogen Uptake at Harvesting Stage}

Nitrogen $(\mathrm{N}) \times$ variety $(\mathrm{V})$ interactions and the individual effect of $\mathrm{V}$ for straw nitrogen uptake (SNUP), grain nitrogen uptake (GNUP) and total nitrogen uptake (TNUP) were insignificant $(\mathrm{P}>0.05)$. The individual effect of $\mathrm{N}$ was significant ( $\mathrm{P}<0.01$ ) for SNUP, GNUP and TNUP (Table 3). In BRRI dhan28, the urea treatment and urea + PM treatment gave the higher $\mathrm{N}$ uptake in rice straw $\left(38 \mathrm{~kg} \cdot \mathrm{ha}^{-1}\right.$ ) followed by urea $+\mathrm{CD}$ treatment $(36$ $\left.\mathrm{kg} \cdot \mathrm{ha}^{-1}\right)$, absolute CD treatment $\left(35 \mathrm{~kg} \cdot \mathrm{ha}^{-1}\right.$ ) and absolute PM treatment $\left(34 \mathrm{~kg} \cdot \mathrm{ha}^{-1}\right)$. The urea + PM treatment had the highest $\mathrm{N}$ uptake in rice grain $\left(66 \mathrm{~kg} \cdot \mathrm{ha}^{-1}\right)$ followed by urea $+\mathrm{CD}$ treatment $\left(62 \mathrm{~kg} \cdot \mathrm{ha}^{-1}\right)$, urea treatment $\left(60 \mathrm{~kg} \cdot \mathrm{ha}^{-1}\right)$ and absolute PM treatment $\left(55 \mathrm{~kg} \cdot \mathrm{ha}^{-1}\right)$. The $\mathrm{N}$ control treatment had the lowest $\mathrm{N}$ uptake both in rice straw and rice grain (Figure 2). The urea + PM treatment had the highest TNUP (104 kg·ha ${ }^{-1}$ ) followed by urea treatment $\left(98 \mathrm{~kg} \cdot \mathrm{ha}^{-1}\right)$ and urea + CD treatment $\left(98 \mathrm{~kg} \cdot \mathrm{ha}^{-1}\right)$. The urea treatment, urea + CD treatment and absolute PM treatment gave statistically similar TNUP. The N control treatment had the lowest TNUP (Figure 2). In $\mathrm{N}$ control treatment, TNUP was $45 \mathrm{~kg} \cdot \mathrm{ha}^{-1}$ of which $64 \%$ accumulated in rice grain and the rest $36 \%$ in

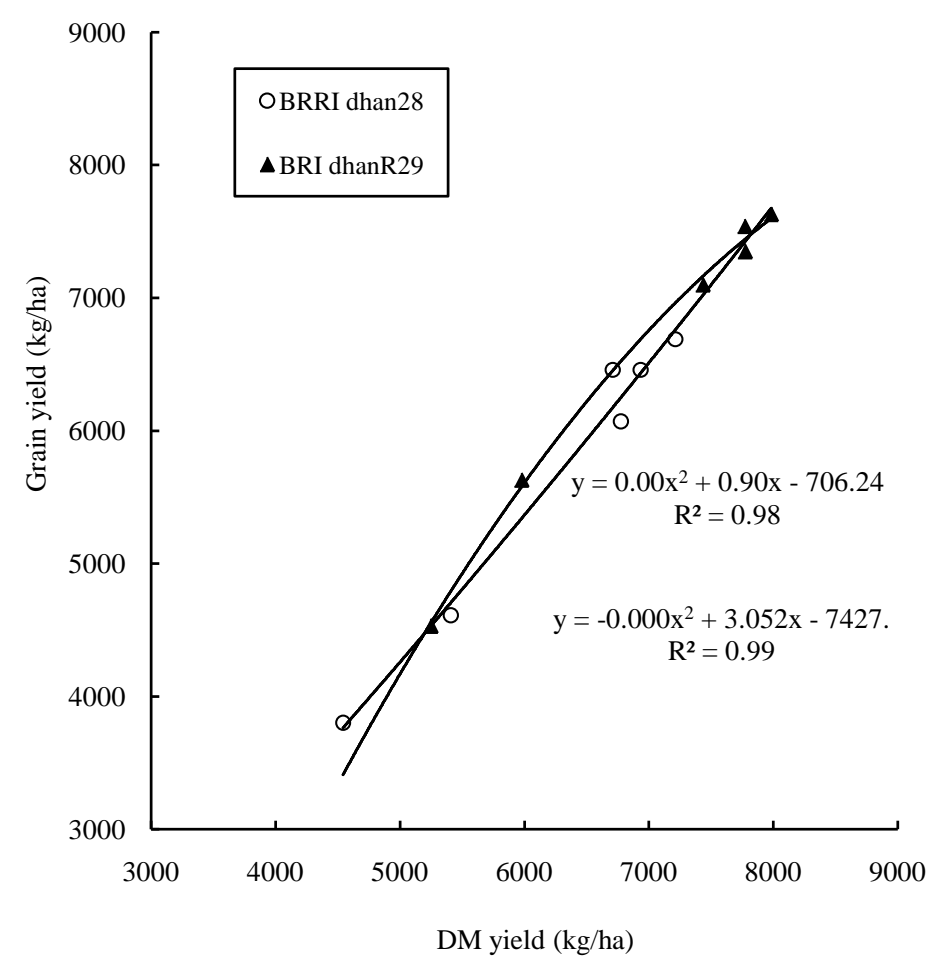

Figure 1. Relationship between dry matter and grain yield production under different nutrient sources. 
Table 3. Nitrogen uptake with different nitrogen treatments in BRRI dhan28 and BRRI dhan29.

\begin{tabular}{|c|c|c|c|}
\hline $\begin{array}{l}\text { Nitrogen source } \\
(\mathrm{N})\left(\mathrm{kg} \cdot \mathrm{ha}^{-1}\right)\end{array}$ & $\operatorname{SNUP}\left(\mathrm{kg} \cdot \mathrm{ha}^{-1}\right)$ & GNUP $\left(\mathrm{kg} \cdot \mathrm{ha}^{-1}\right)$ & TNUP $\left(\mathrm{kg} \cdot \mathrm{ha}^{-1}\right)$ \\
\hline \multicolumn{4}{|c|}{ BRRI dhan28 } \\
\hline Control & 16 & 29 & 45 \\
\hline Urea & 38 & 60 & 98 \\
\hline Urea + CD & 36 & 62 & 98 \\
\hline $\mathrm{CD}$ & 35 & 49 & 84 \\
\hline Urea + PM & 38 & 66 & 104 \\
\hline PM & 34 & 55 & 89 \\
\hline Average & 33 & 54 & 87 \\
\hline NHI & & 0.63 & \\
\hline \multicolumn{4}{|c|}{ BRRI dhan29 } \\
\hline Control & 18 & 30 & 48 \\
\hline Urea & 38 & 66 & 104 \\
\hline Urea + CD & 39 & 73 & 112 \\
\hline CD & 34 & 56 & 91 \\
\hline Urea + PM & 33 & 76 & 109 \\
\hline $\mathrm{PM}$ & 32 & 61 & 93 \\
\hline Average & 32 & 60 & 92 \\
\hline NHI & & 0.65 & \\
\hline $\mathrm{LSD}_{0.05}$ for $\mathrm{N}$ & 7.61 & 11.99 & 18.30 \\
\hline $\mathrm{LSD}_{0.05}$ for V & NS & NS & NS \\
\hline $\mathrm{LSD}_{0.05}$ for $\mathrm{N} \times \mathrm{V}$ & NS & NS & NS \\
\hline CV (\%) & 23.0 & 20.7 & 20.1 \\
\hline
\end{tabular}

NS: non-significant at the 0.05 probability levels.

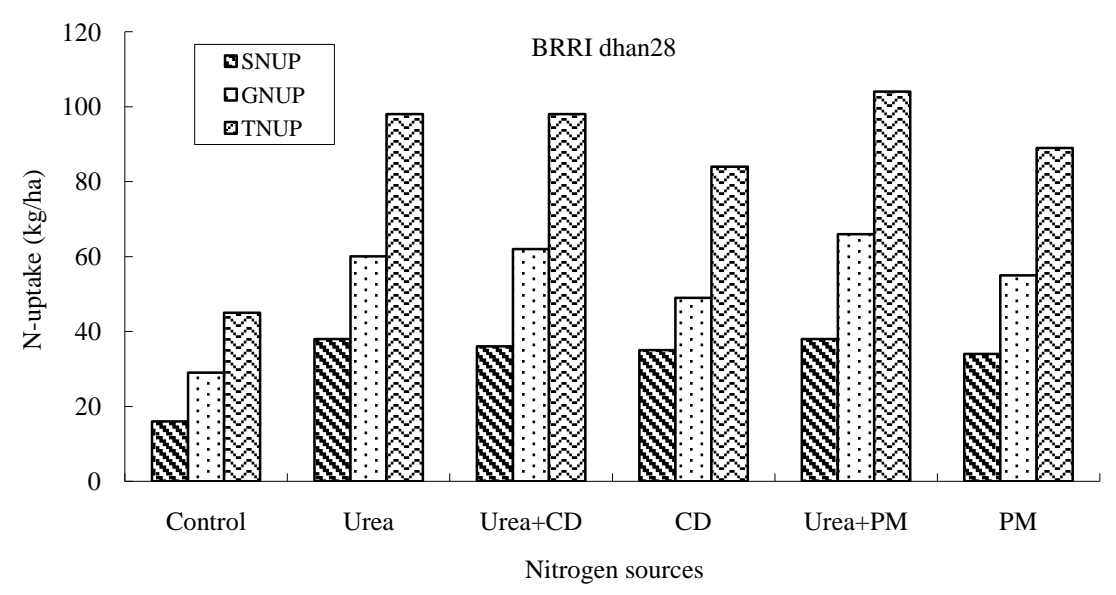

Figure 2. Relationship between nitrogen uptake and different nitrogen sources in BRRI dhan28. 
rice straw. Under urea treatment, TNUP was $98 \mathrm{~kg} \cdot \mathrm{ha}^{-1}$ of which $61 \%$ accumulated in rice grain and the rest $39 \%$ remained in rice straw. Under urea + CD treatment, TNUP was $98 \mathrm{~kg} \cdot \mathrm{ha}^{-1}$ of which $63 \% \mathrm{~N}$ uptake was observed in rice grain and $37 \% \mathrm{~N}$ uptake was in rice straw. Under absolute CD treatment, TNUP was $84 \mathrm{~kg} \cdot \mathrm{ha}^{-1}$ of $^{-}$ which $58 \% \mathrm{~N}$ uptake was observed in rice grain and the rest $42 \% \mathrm{~N}$ uptake was in rice straw. Similarly, in urea + PM treatment and absolute PM treatment, TNUP was $104 \mathrm{~kg} \cdot \mathrm{ha}^{-1}$ and $89 \mathrm{~kg} \cdot \mathrm{ha}^{-1}$ of which $63 \%$ and $62 \% \mathrm{~N}$ uptake was observed in rice grain and the rest $37 \%$ and $38 \%$ was in rice straw, respectively (Table 3 ). In BRRI dhan29, the urea $+\mathrm{CD}$ treatment had the highest $\mathrm{N}$ uptake in rice straw $\left(39 \mathrm{~kg} \cdot \mathrm{ha}^{-1}\right)$ followed by absolute urea treatment $\left(38 \mathrm{~kg} \cdot \mathrm{ha}^{-1}\right)$ and absolute CD treatment $\left(34 \mathrm{~kg} \cdot \mathrm{ha}^{-1}\right)$. The absolute CD treatment, urea + PM treatment and absolute PM treatment gave statistically similar $\mathrm{N}$ uptake in rice straw. The $\mathrm{N}$ control treatment had the lowest $\mathrm{N}$ uptake in rice straw $\left(18 \mathrm{~kg} \cdot \mathrm{ha}^{-1}\right.$ ) (Figure 3). The urea $+\mathrm{PM}$ treatment had the highest $\mathrm{N}$ uptake in rice grain $\left(76 \mathrm{~kg} \cdot \mathrm{ha}^{-1}\right)$ followed by urea $+\mathrm{CD}$ treatment $\left(73 \mathrm{~kg} \cdot \mathrm{ha}^{-1}\right)$ and urea treatment $\left(66 \mathrm{~kg} \cdot \mathrm{ha}^{-1}\right)$. The urea treatment, absolute PM treatment and absolute CD treatment gave statistically similar $\mathrm{N}$ uptake in rice grain. The $\mathrm{N}$ control treatment had the lowest $\mathrm{N}$ uptake in rice grain $\left(30 \mathrm{~kg} \cdot \mathrm{ha}^{-1}\right)$ (Figure 3$)$. The urea $+\mathrm{CD}$ treatment had the highest TNUP $\left(112 \mathrm{~kg} \cdot \mathrm{ha}^{-1}\right)$ followed by urea + PM treatment $\left(109 \mathrm{~kg} \cdot \mathrm{ha}^{-1}\right)$ and urea treatment $\left(\mathrm{kg} \cdot \mathrm{ha}^{-1}\right)$. The absolute CD treatment and absolute PM treatment gave statistically similar TNUP. The $\mathrm{N}$ control treatment gave the lowest TNUP (48 kg.ha ${ }^{-1}$ ) (Figure 3). In BRRI dhan29, TNUP was $48 \mathrm{~kg} \cdot \mathrm{ha}^{-1}$ of which $62 \% \mathrm{~N}$ uptake was observed in rice grain and the rest $38 \% \mathrm{~N}$ uptake was in rice straw under $\mathrm{N}$ control treatment. In urea treatment, TNUP was $104 \mathrm{~kg} \cdot \mathrm{ha}^{-1}$ of which $63 \% \mathrm{~N}$ uptake was observed in rice grain and the rest $37 \% \mathrm{~N}$ uptake was in rice straw. In urea $+\mathrm{CD}$ treatment, TNUP was $112 \mathrm{~kg} \cdot \mathrm{ha}^{-1}$ of which $65 \% \mathrm{~N}$ uptake was observed in rice grain and the rest $35 \% \mathrm{~N}$ uptake was in rice straw. In absolute CD treatment, TNUP was $91 \mathrm{~kg} \cdot \mathrm{ha}^{-1}$ of which $62 \% \mathrm{~N}$ uptake was occurred in rice grain and the rest $38 \% \mathrm{~N}$ uptake was observed in rice straw. In urea + PM treatment, TNUP was $109 \mathrm{~kg} \cdot \mathrm{ha}^{-1}$ of which $70 \% \mathrm{~N}$ uptake was observed in rice grain and the rest $30 \%$ was remained in rice straw. In absolute PM treatment, TNUP was $93 \mathrm{~kg} \cdot \mathrm{ha}^{-1}$ of which $66 \% \mathrm{~N}$ uptake was observed in rice grain and the rest $34 \% \mathrm{~N}$ uptake was in rice straw. Irrespective of $\mathrm{N}$ treatments, average TNUP in BRRI dhan28 was $87 \mathrm{~kg} \cdot \mathrm{ha}^{-1}$ of which $62 \% \mathrm{~N}$ uptake in rice grain and the rest $38 \% \mathrm{~N}$ uptake was in rice straw. Similarly in BRRI dhan 29 , average TNUP was $92 \mathrm{~kg} \cdot \mathrm{ha}^{-1}$ of which $65 \% \mathrm{~N}$ uptake was observed in rice grain and the rest $35 \% \mathrm{~N}$ uptake was in rice straw (Table 3). In both the varieties, GNUP was higher in comparison to SNUP in all the treatments. Because $\mathrm{N}$ uptake increased dry matter production up to flowering stage and decreased thereafter due to pollen falls and tiller senescence. [26] reported that at harvest, more $\mathrm{N}$ was accumulated in grains than in dry matter. It might be explained by the $\mathrm{N}$ harvest index ( $\mathrm{N}$ accumulation in grains $/ \mathrm{N}$ accumulation in grains plus dry matter). In BRRI dhan28, nitrogen harvest index (NHI) across the nitrogen treatments was 0.63. This means that $63 \%$ of the absorbed $\mathrm{N}$ was translocated to the grains and $37 \%$ remained in the dry matter. In BRRI dhan 29 , the NHI value was 0.65 . This also means that $65 \%$ of the absorbed $\mathrm{N}$ was translocated to the grain and $35 \%$ remained in the dry matter. [27] reported that NHI values varied from 0.60 to 0.72 for three IRRI semi dwarf rice cultivars differing in growth duration. [28] reported NHI values of 0.58 and 0.62 in two lowland rice cultivars in West Africa.

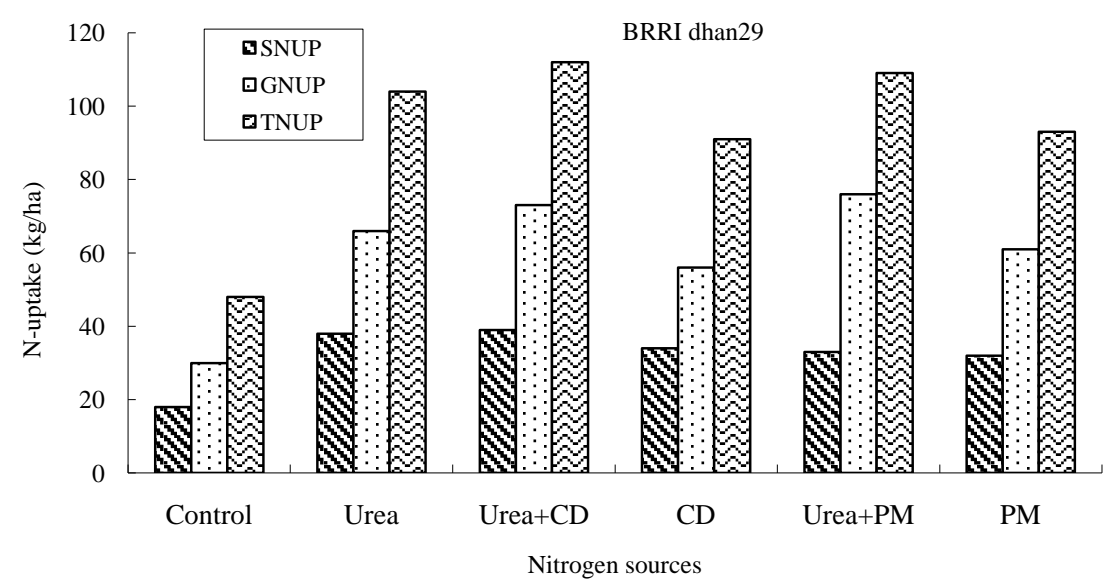

Figure 3. Relationship between nitrogen uptake and different nitrogen sources in BRRI dhan29. 


\subsection{Nitrogen Use Efficiency (NUE)}

Application of $164 \mathrm{~kg} \mathrm{~N}$ ha $^{-1}$ through different sources influenced nitrogen use efficiency. In BRRI dhan28, the urea treatment had the highest AE $\left(18 \mathrm{~kg} \cdot \mathrm{kg}^{-1}\right)$ followed by urea + PM treatment $\left(16 \mathrm{~kg} \cdot \mathrm{kg}^{-1}\right)$ and absolute PM treatment $\left(16 \mathrm{~kg} \cdot \mathrm{kg}^{-1}\right)$. The AE of urea + CD treatment was significantly lower in comparison to urea treatment, urea + PM treatment and absolute PM treatment. The absolute CD treatment had the lowest AE $\left(5 \mathrm{~kg} \cdot \mathrm{kg}^{-1}\right)$. It was probably due to slow mineralization of CD in comparison to urea and PM. In BRRI dhan28, the average AE was $14 \mathrm{~kg}$ grain produced per $\mathrm{kg} \mathrm{N}$ applied across $\mathrm{N}$ sources. In BRRI dhan29, the urea + PM treatment had the highest AE $\left(19 \mathrm{~kg} \cdot \mathrm{kg}^{-1}\right)$ followed by absolute urea treatment $\left(18 \mathrm{~kg} \cdot \mathrm{kg}^{-1}\right)$. The urea + CD treatment gave significantly higher AE in comparison to absolute $\mathrm{CD}$ treatment. The urea $+\mathrm{CD}$ treatment and absolute PM treatment gave similar AE. The absolute CD treatment had the lowest AE $\left(7 \mathrm{~kg} \cdot \mathrm{kg}^{-1}\right)$. In BRRI dhan29, the average AE was $15 \mathrm{~kg}$ grain produced per $\mathrm{kg} \mathrm{N}$ applied across $\mathrm{N}$ sources. Under urea + CD treatment, BRRI dhan 29 gave significantly higher AE in comparison to BRRI dhan28. Under absolute urea treatment and absolute PM treatment BRRI dhan28 and BRRI dhan29 gave statistically similar AE.

Under absolute CD treatment and urea + PM treatment, BRRI dhan29 gave significantly higher AE in comparison to BRRI dhan28. The average agronomic efficiency (AE) was $14 \mathrm{~kg} \cdot \mathrm{kg}^{-1}$ (i.e. $14 \mathrm{~kg}$ grain produced per $\mathrm{kg} \mathrm{N}$ applied) in BRRI dhan28 and $15 \mathrm{~kg} \cdot \mathrm{kg}^{-1}$ in BRRI dhan29 across $\mathrm{N}$ sources. The use of urea solely or in conjunction with poultry manure gave comparatively higher AE than those of CD. Agronomic efficiency is usually greater at the quick mineralized material than slow mineralized material of $\mathrm{N}$ source. Poultry manure has a higher nutrient content and more rapid mineralization rate compared to other animal manures [29]. [26] reported that agronomic efficiency was $23 \mathrm{~kg}$ grain produced per $\mathrm{kg} \mathrm{N}$ applied in flooded rice cultivar Metica 1. [5] also reported agronomic efficiency in lowland rice in the tropics in the range of 15 to $25 \mathrm{~kg}$ grain produced per $\mathrm{kg}$ of applied N. In BRRI dhan28, the absolute PM treatment gave the highest physiological efficiency (PE) (144 $\left.\mathrm{kg} \cdot \mathrm{kg}^{-1}\right)$ followed by absolute urea treatment $\left(117 \mathrm{~kg} \cdot \mathrm{kg}^{-1}\right)$ (Table 4). In absolute PM treatment, PE was $144 \mathrm{~kg}$ biological yield (straw + grain) per unit of $\mathrm{N}$ accumulated whereas in urea treatment PE was $117 \mathrm{~kg}$ biological yield per unit of $\mathrm{N}$ accumulated. All the $\mathrm{N}$ sources gave statistically similar PE except absolute CD treatment. The absolute CD treatment had the lowest PE $\left(38 \mathrm{~kg} \cdot \mathrm{kg}^{-1}\right)$. In BRRI dhan28, the average PE was $94 \mathrm{~kg}$ biological yield per unit of $\mathrm{N}$ accumulated across $\mathrm{N}$ sources. In BRRI dhan29, the absolute PM treatment had the highest PE $\left(167 \mathrm{~kg} \cdot \mathrm{kg}^{-1}\right)$ followed by urea treatment $\left(131 \mathrm{~kg} \cdot \mathrm{kg}^{-1}\right)$ and urea + PM treatment $\left(119 \mathrm{~kg} \cdot \mathrm{kg}^{-1}\right)$. The absolute PM treatment gave significantly higher PE in comparison to urea + CD treatment. The absolute CD treatment had the lowest PE (48 $\left.\mathrm{kg} \cdot \mathrm{kg}^{-1}\right)$. In BRRI dhan29, the average PE was $110 \mathrm{~kg}$ biological yield per unit of $\mathrm{N}$ accumulated across $\mathrm{N}$ sources. In BRRI dhan28, the absolute PM treatment had the highest agro physiological efficiency (APE) $\left(75 \mathrm{~kg} \cdot \mathrm{kg}^{-1}\right)$ followed by absolute urea treatment $\left(61 \mathrm{~kg} \cdot \mathrm{kg}^{-1}\right)$. In absolute PM treatment, APE was $75 \mathrm{~kg}$ grain produced per $\mathrm{kg}$ of $\mathrm{N}$ accumulated in the grain and straw whereas in urea treatment $61 \mathrm{~kg}$ grain produced per $\mathrm{kg}$ of $\mathrm{N}$ accumulated in the grain and straw. All the $\mathrm{N}$ treatments gave statistically similar APE except absolute CD treatment. The absolute CD treatment had the lowest APE $\left(21 \mathrm{~kg} \cdot \mathrm{kg}^{-1}\right)$. In BRRI dhan29, the absolute PM treatment had the highest APE followed by urea treatment $\left(69 \mathrm{~kg} \cdot \mathrm{kg}^{-1}\right)$ and urea + PM treatment $\left(61 \mathrm{~kg} \cdot \mathrm{kg}^{-1}\right)$. The APE from absolute PM treatment was significantly higher in comparison to that of urea + CD treatment. The absolute CD treatment had the lowest APE was observed in $\left(28 \mathrm{~kg} \cdot \mathrm{kg}^{-1}\right)(\mathrm{Ta}-$ ble 4). [26] reported that APE was $63 \mathrm{~kg}$ grain produced per $\mathrm{kg}$ of $\mathrm{N}$ accumulated in the grain and straw across $\mathrm{N}$ rates. The apparent recovery efficiency (ARE) ranged from $24 \%-39 \%$ irrespective of $\mathrm{N}$ sources and variety. [26] reported an apparent recovery efficiency of $39 \%$ across different $\mathrm{N}$ rates in flooded rice cultivar Metica 1. The percentage of $\mathrm{N}$ recovery varies with soil properties, methods, amounts and timing of fertilizer application and other management practices. It usually ranges from $30 \%-50 \%$ in the tropics [30]. [31] also reported a $\mathrm{N}$ recovery efficiency of $37 \%$ in 20 lowland rice genotypes. The low $\mathrm{N}$ recovery efficiency in low land rice may be related to $\mathrm{N}$ losses from soil via nitrification-denitrification, $\mathrm{NH}_{3}$ volatilization, or leaching [32].

In BRRI dhan28, the urea treatment had the highest utilization efficiency (UE) (34 $\left.\mathrm{kg} \cdot \mathrm{kg}^{-1}\right)$ followed by urea + PM treatment $\left(30 \mathrm{~kg} \cdot \mathrm{kg}^{-1}\right)$ and absolute PM treatment $\left(31 \mathrm{~kg} \cdot \mathrm{kg}^{-1}\right)$. The urea treatment gave significantly higher UE in comparison to urea + CD treatment. The absolute CD treatment had the lowest UE $\left(9 \mathrm{~kg}^{-\mathrm{kg}^{-1}}\right)$. In BRRI dhan29, the urea + PM treatment had highest UE $\left(37 \mathrm{~kg} \cdot \mathrm{kg}^{-1}\right)$ followed by urea treatment $\left(35 \mathrm{~kg} \cdot \mathrm{kg}^{-1}\right)$ and urea + CD treatment $\left(33 \mathrm{~kg} \cdot \mathrm{kg}^{-1}\right)$. The urea + PM treatment gave significantly higher UE in comparison to absolute PM treatment. The absolute CD treatment had lowest UE $\left(11 \mathrm{~kg}^{-1} \mathrm{~kg}^{-1}\right)$. Under urea + CD treatment and urea + PM treatment, BRRI dhan29 gave significantly higher UE in comparison to BRRI dhan28. Under urea 
Table 4. Nitrogen use efficiencies of two rice varieties under different nitrogen sources.

\begin{tabular}{|c|c|c|c|c|c|c|}
\hline $\begin{array}{l}\text { Nitrogen source } \\
(\mathrm{N})\left(\mathrm{kg} \cdot \mathrm{ha}^{-1}\right)\end{array}$ & $\begin{array}{l}\text { Agronomic } \\
\text { efficiency } \\
\left(\mathrm{kg} \cdot \mathrm{kg}^{-1}\right)\end{array}$ & $\begin{array}{l}\text { Physiological } \\
\text { efficiency } \\
\left(\mathrm{kg}^{\mathrm{k}} \mathrm{kg}^{-1}\right)\end{array}$ & $\begin{array}{l}\text { Agro-physiological } \\
\text { efficiency } \\
\left(\mathrm{kg} \cdot \mathrm{kg}^{-1}\right)\end{array}$ & $\begin{array}{c}\text { Apparent } \\
\text { recovery } \\
\text { efficiency (\%) }\end{array}$ & $\begin{array}{l}\text { Utilization } \\
\text { efficiency } \\
\left(\mathrm{kg} \cdot \mathrm{kg}^{-1}\right)\end{array}$ & $\begin{array}{l}\text { Partial factor } \\
\text { productivity } \\
\left(\mathrm{kg}^{\mathrm{kg}} \mathrm{kg}^{-1}\right)\end{array}$ \\
\hline \multicolumn{7}{|c|}{ BRRI dhan28 } \\
\hline Urea & 18 & 117 & 61 & 33 & 34 & 41 \\
\hline Urea + CD & 14 & 85 & 44 & 33 & 27 & 37 \\
\hline $\mathrm{CD}$ & 5 & 38 & 21 & 24 & 9 & 28 \\
\hline Urea + PM & 16 & 84 & 45 & 36 & 30 & 39 \\
\hline $\mathrm{PM}$ & 16 & 144 & 75 & 27 & 31 & 39 \\
\hline Avg. & 14 & 94 & 49 & 31 & 26 & 37 \\
\hline \multicolumn{7}{|c|}{ BRRI dhan29 } \\
\hline Urea & 18 & 131 & 69 & 34 & 35 & 46 \\
\hline Urea + CD & 17 & 87 & 45 & 39 & 33 & 45 \\
\hline $\mathrm{CD}$ & 7 & 48 & 28 & 26 & 11 & 34 \\
\hline Urea + PM & 19 & 119 & 61 & 37 & 37 & 47 \\
\hline PM & 16 & 167 & 86 & 27 & 30 & 43 \\
\hline Avg. & 15 & 110 & 58 & 33 & 29 & 43 \\
\hline $\mathrm{LSD}_{0.05}$ for $\mathrm{N}$ & 1.80 & 72.39 & 36.77 & NS & 4.30 & 1.66 \\
\hline $\mathrm{LSD}_{0.05}$ for $\mathrm{V}$ & 1.14 & NS & NS & NS & 2.72 & 1.05 \\
\hline $\mathrm{LSD}_{0.05}$ for $\mathrm{N} \times \mathrm{V}$ & NS & NS & NS & NS & NS & NS \\
\hline CV (\%) & 12.1 & 69.2 & 66.8 & 37.7 & 15.2 & 4.1 \\
\hline
\end{tabular}

NS: non-significant at the 0.05 probability levels.

treatment, absolute CD treatment and absolute PM treatment, BRRI dhan28 and BRRI dhan29 gave statistically similar UE (Table 4.2.10). [26] reported that utilization efficiency was $58 \mathrm{~kg} \cdot \mathrm{kg}^{-1}$ for flooded rice cultivar Metica1 i.e. $58 \mathrm{~kg}$ grain produced per kg $\mathrm{N}$ utilized across the $\mathrm{N}$ rates. [5] also reported that the efficiency of utilization for grain production in the tropics is about $50 \mathrm{~kg}$ grain per $\mathrm{kg} \mathrm{N}$ absorbed, and this efficiency appears to be almost constant regardless of the rice yields achieved. In BRRI dhan28, the urea treatment gave the highest partial factor productivity (PFP) $\left(41 \mathrm{~kg} \cdot \mathrm{kg}^{-1}\right)$ followed by urea + PM treatment and absolute PM treatment (39 $\left.\mathrm{kg} \cdot \mathrm{kg}^{-1}\right)$. The absolute PM treatment and urea + PM treatment gave significantly higher PFP $\left(39 \mathrm{~kg} \cdot \mathrm{kg}^{-1}\right)$ in comparison to urea + CD treatment $\left(37 \mathrm{~kg} \cdot \mathrm{kg}^{-1}\right)$. The absolute CD treatment gave the lowest PFP $\left(28 \mathrm{~kg} \cdot \mathrm{kg}^{-1}\right)$. In BRRI dhan29, the urea + PM treatment gave the highest PFP $\left(47 \mathrm{~kg} \mathrm{~kg}^{-1}\right)$ followed by urea treatment (46 $\left.\mathrm{kg} \cdot \mathrm{kg}^{-1}\right)$ and urea $+\mathrm{CD}$ treatment $\left(45 \mathrm{~kg} \cdot \mathrm{kg}^{-1}\right)$ (Table 4). The urea + CD treatment gave significantly higher PFP than the absolute PM treatment. The absolute CD treatment gave the lowest PFP $\left(34 \mathrm{~kg} \cdot \mathrm{kg}^{-1}\right)$. Application of same amount of $\mathrm{N}\left(164 \mathrm{~kg} \cdot \mathrm{ha}^{-1}\right)$ from different sources varied the $\mathrm{N}$-supplying capacity due to mineralization capacity of the materials. PFP was $40 \mathrm{~kg}$ grain produced per $\mathrm{kg} \mathrm{N}$ applied averaged over $\mathrm{N}$ sources and varieties. The lowest PFP produced from absolute CD treatment due to slow mineralization of CD. In BRRI dhan28, the N control treatment gave the highest internal use efficiency (IUE) $\left(86 \mathrm{~kg} \cdot \mathrm{kg}^{-1}\right)$ followed by absolute PM treatment $\left(75 \mathrm{~kg} \cdot \mathrm{kg}^{-1}\right)$ and urea treatment $\left(71 \mathrm{~kg} \cdot \mathrm{kg}^{-1}\right)$. Urea + CD treatment and urea + PM treatment gave statistically similar IUE. The absolute CD treatment gave the lowest IUE $\left(56 \mathrm{~kg} \cdot \mathrm{kg}^{-1}\right)$. In BRRI dhan29, the $\mathrm{N}$ control treatment gave the highest IUE $\left(94 \mathrm{~kg} \cdot \mathrm{kg}^{-1}\right)$ followed by absolute PM treatment $\left(81 \mathrm{~kg} \cdot \mathrm{kg}^{-1}\right)$ and absolute urea treatment $\left(77 \mathrm{~kg} \cdot \mathrm{kg}^{-1}\right.$ ) (Table 5). Urea + PM treatment, urea + CD treatment and absolute CD treatment performed statistically similar IUE. The apparently lower IUE was observed in absolute CD treatment $\left(64 \mathrm{~kg} \cdot \mathrm{kg}^{-1}\right)$. Internal use efficiency was $72 \mathrm{~kg} \cdot \mathrm{kg}^{-1}$ averaged over $\mathrm{N}$ sources and varieties i.e. were $72 \mathrm{~kg}$ grain produced per 
Table 5. Nitrogen use efficiencies of two rice varieties under different nitrogen sources.

\begin{tabular}{|c|c|c|}
\hline $\begin{array}{l}\text { Nitrogen source }(\mathrm{N}) \\
\left(\mathrm{kg} \cdot \mathrm{ha}^{-1}\right)\end{array}$ & $\begin{array}{l}\text { Internal use efficiency } \\
\text { (IUE) }\left(\mathrm{kg}^{\mathrm{kgg}} \mathrm{kg}^{-1}\right)\end{array}$ & $\begin{array}{l}\text { Reciprocal of internal use } \\
\text { efficiency (RIE) }\left(\mathrm{kg} \cdot \mathrm{kg}^{-1}\right)\end{array}$ \\
\hline \multicolumn{3}{|c|}{ BRRI dhan28 } \\
\hline Control & 86 & 12 \\
\hline Urea & 71 & 15 \\
\hline Urea + CD & 62 & 16 \\
\hline CD & 56 & 18 \\
\hline Urea + PM & 62 & 16 \\
\hline PM & 75 & 14 \\
\hline Avg. & 69 & 15 \\
\hline \multicolumn{3}{|c|}{ BRRI dhan29 } \\
\hline Control & 94 & 11 \\
\hline Urea & 77 & 14 \\
\hline Urea + CD & 67 & 15 \\
\hline $\mathrm{CD}$ & 64 & 16 \\
\hline Urea + PM & 72 & 14 \\
\hline $\mathrm{PM}$ & 81 & 13 \\
\hline Avg. & 76 & 14 \\
\hline $\mathrm{LSD}_{0.05}$ for $\mathrm{N}$ & 15.02 & 2.91 \\
\hline $\mathrm{LSD}_{0.05}$ for $\mathrm{V}$ & NS & NS \\
\hline $\mathrm{LSD}_{0.05}$ for $\mathrm{N} \times \mathrm{V}$ & NS & NS \\
\hline CV (\%) & 20.4 & 19.7 \\
\hline
\end{tabular}

NS: non-significant at the 0.05 probability levels.

$\mathrm{kg}$ of total $\mathrm{N}$ uptake in the grain and straw. [2] reported that the internal $\mathrm{N}$ use efficiency varied from 46 to 76 $\mathrm{kg}$ grain per kg plant $\mathrm{N}$ uptake across the treatments and years. In BRRI dhan28, reciprocal of internal use efficiency (RIUE) (kg N required to produced 1 ton of grain) varied from $12-18 \mathrm{~kg} \cdot \mathrm{t}^{-1}$ and in BRRI dhan29, RIUE

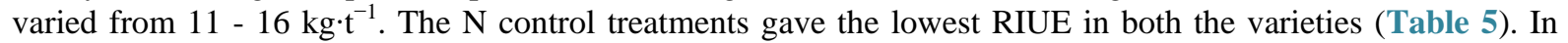
BRRI dhan28, the highest RIUE was observed in absolute CD treatment $\left(18 \mathrm{~kg} \cdot \mathrm{t}^{-1}\right)$ followed by urea + CD treatment $\left(16 \mathrm{~kg} \cdot \mathrm{t}^{-1}\right)$ and urea + PM treatment $\left(16 \mathrm{~kg} \cdot \mathrm{t}^{-1}\right)$. The absolute PM treatment, urea + PM treatment and urea treatment gave statistically similar RIUE. In BRRI dhan29, the absolute CD treatment gave the highest RIUE $\left(16 \mathrm{~kg} \cdot \mathrm{t}^{-1}\right)$ followed by urea + CD treatment $\left(15 \mathrm{~kg} \cdot \mathrm{t}^{-1}\right)$. The urea + PM treatment, urea treatment and absolute PM treatment gave statistically similar RIUE. [33] reported mean RIUE of $16.4 \mathrm{~kg} \cdot \mathrm{t}^{-1}$ with full fertilization and $12.8 \mathrm{~kg} \cdot \mathrm{t}^{-1}$ in $-\mathrm{N}$ plots.

\section{Conclusion}

Managing the $\mathrm{N}$ application to rice is an essential to reduce $\mathrm{N}$ losses, improve $\mathrm{N}$ use efficiency and obtain higher yield. The use of urea solely or in conjunction with poultry manure gave comparatively higher $\mathrm{N}$ use efficiency than that of cowdung. Thus the doses of chemical fertilizer can be reduced by $50 \%$ by using poultry manure in dry season. 


\section{References}

[1] Fageria, N.K., Santos, A.B. and Cutrim, V.A. (2008) Dry Matter and Yield of Lowland Rice Genotypes as Influence by Nitrogen Fertilization. Journal of Plant Nutrition, 31, 788-795. http://dx.doi.org/10.1080/01904160801928471

[2] Saleque, M.A., Abedin, M.J., Bhuiyan, N.I., Zaman, S.K. and Panaullah, G.M. (2004) Long-Term Effects of Inorganic and Organic Fertilizer Sources on Yield and Nutrient Accumulation of Lowland Rice. Field Crops Research, 86, 53-65. http://dx.doi.org/10.1016/S0378-4290(03)00119-9

[3] Chaturvedi, I. (2005) Effect of Nitrogen Fertilizers on Growth, Yield and Quality of Hybrid Rice. Journal of Central European Agriculture, 6, 611-618.

[4] Mikkelsen, D.S., Jayaweera, G.R. and Rolston, D.E. (1995) Nitrogen Fertilizer Practices of Lowland Rice Culture. In: Nitrogen Fertilization and the Environment, 171-223.

[5] Yoshida, S. (1981) Fundamentals of Rice Crop Science. IRRI, Los Banos, 235-269.

[6] Datta, S.K.D. (1986) Improving Nitrogen Fertilizer Efficiency in Lowland Rice in Tropical Asia. Fertilizer Research, 9, 171-186. http://dx.doi.org/10.1007/BF01048702

[7] Fageria, N.K. and Filho, M.P.B. (2001) Nitrogen Use Efficiency in Lowland Rice Genotypes. Communications in Soil Science and Plant Analysis, 32, 2079-2089. http://dx.doi.org/10.1081/CSS-120000270

[8] Yadav, R.L., Yadav, D.S., Singh, R.M. and Kumar, A. (1998) Long-Term Effects of Inorganic Fertilizer Inputs on Crop Productivity in a Rice-Wheat Cropping System. Nutrient Cycling in Agroecosystems, 51, 193-200.

http://dx.doi.org/10.1023/A:1009744719420

[9] Panda, S.C. (2006) Production Technology of Crop Management and Integrated Farming. Agrobios (India), 130.

[10] Solaiman, A.R.M. and Rabbani, M.G. (2006) Effects of N P K S and Cow Dung on Growth and Yield of Tomato. Bulletin Institute of Tropical Agriculture, 29, 31-37.

[11] Zhang, W.D., Han, Y., Dick, W.A., Davis, K.R. and Hoitink, H.A.J. (1998) Compost and Compost Water Extract Induced Systemic Acquired Resistance in Cucumber and Arabidopsis. Phytopathology, 88, 450-455. http://dx.doi.org/10.1094/PHYTO.1998.88.5.450

[12] Ishak, C.F., Bakar, R.A., Saud, H.M. and Abdullah, T.L. (1999) Application of Sewage Sludge from Indian Water Treatment Plants. AgroSearch, 6, 14-19.

[13] Wu, J., Nofziger, D.L., Warren, J. and Hattey, J. (2003) Estimating Ammonia Volatilization from Swine-Effluent Droplets in Sprinkle Irrigation. Soil Science Society of America Journal, 67, 1352-1360. http://dx.doi.org/10.2136/sssaj2003.1352

[14] Yoshida, S., Forno, D.A., Cock, J.H. and Gomez, K.A. (1976) Laboratory Manual for Physiological Studies of Rice. 3rd Edition, International Rice Research Institute, Manila.

[15] Yoshida, S., Cock, J.H. and Parao, F.T. (1972) Physiological Aspects of High Yield. In: Rice Breeding, International Rice Research Institute, Los Baños, 455-469.

[16] Fageria, N.K., Santos, A.B. and Baligar, V.C. (1997) Phosphorus Soil Test Calibration for Lowland Rice on an Inceptisol. Agronomy Journal, 89, 737-742. http://dx.doi.org/10.2134/agronj1997.00021962008900050005x

[17] Gomez, K.A. and Gomez, A.A. (1984) Statistical Procedure for Agricultural Research. 2nd Edition, John Willey and Sons, Singapore City, 28-192.

[18] Dawe, D., Dobermann, A., Moya, P., Abulrachmann, S., Singh, B., Lal, P., Li, S.Y., Lin, B., Panaullah, G.M., Sariam, O., Singh, Y., Swarup, A., Tan, P.S. and Zhen, Q.X. (2000) How Widespread Are Yield Declines in Long-Term Rice Experiments in Asia? Field Crops Research, 66, 175-193. http://dx.doi.org/10.1016/S0378-4290(00)00075-7

[19] Statcal (2012) http://www.danielsoper.com/statcalc3/calc.aspx?id=15

[20] Castellanos, J.Z. and Pratt, P.F. (1981) Mineralization of Manure Nitrogen-Correlation with Laboratory Indexes. Soil Science Society of America Journal, 45, 354-357. http://dx.doi.org/10.2136/sssaj1981.03615995004500020025x

[21] Kelling, K.A., Bundy, L.G., Combs, S.M. and Peters, J.B. (1998) Soil Test Recommendations for Field, Vegetable and Fruit Crops. University of Wisconsin-Extension Bulletin, A2809, Madison.

[22] Myint, A.K., Yamakawa, T., Zenmyo, T., Thao, H.T.B. and Sarr, P.S. (2011) Effects of Organic Manure Application on Growth, Grain Yield and Nitrogen, Phosphorus and Potassium Recoveries of Rice Variety Manawthuka in Paddy Soils of Differing Fertility. Communications in Soil Science and Plant Analysis, 42, 457-474. http://dx.doi.org/10.1080/00103624.2011.542223

[23] Singh, P. and Gangwar, B. (2000) Nitrogen Substitution through FYM in Maize-Wheat Cropping Sequence under Irrigated Conditions. Proceedings of International Conference on Managing Natural Resources for Sustainable Agricultural Production in the 21st Century, New Delhi, 881-882.

[24] Khan, A.R., Sarkar, S., Nanda, P. and Chandra, D. (2001) Organic Manuring through Gliricidia Maculate for Rice 
Production. International Centre for Theoretical Physics, Trieste, Italy Int. Rep., Vol. 10, 1-4.

[25] Antil, R.S. and Singh, M. (2007) Effects of Organic Manures and Fertilizers on Organic Matter and Nutrients Status of the Soil. Archives of Agronomy and Soil Science, 53, 519-528. http://dx.doi.org/10.1080/03650340701571033

[26] Fageria, N.K. and Baligar, V.C. (2001) Lowland Rice Response to Nitrogen Fertilization. Communications in Soil Science and Plant Analysis, 32, 1405-1429. http://dx.doi.org/10.1081/CSS-100104202

[27] Dingkuhn, M., Schnier, H.F., Datta, S.K.D., Dorfling, K. and Javellana, C. (1991) Relationships between Ripening Phase Productivity and Crop Duration, Canopy Photosynthesis and Senescence in Transplanted and Direct-Seeded Lowland Rice. Field Crops Research, 26, 327-345. http://dx.doi.org/10.1016/0378-4290(91)90009-K

[28] Guindo, D., Norman, R.J. and Wells, B.R. (1994) Accumulation of Fertilizer Nitrogen-15 by Rice at Different Stages of Development. Soil Science Society of America Journal, 58, 410-415. http://dx.doi.org/10.2136/sssaj1994.03615995005800020025x

[29] Sims, J.T. and Wolf, D.C. (1994) Poultry Waste Management: Agricultural and Environmental Issues. Advances in Agronomy, 52, 1-83. http://dx.doi.org/10.1016/S0065-2113(08)60621-5

[30] Prasad, R. and Datta, S.K.D. (1979) Increasing Efficiency of Fertilizer Nitrogen in Wetland Rice. In: Nitrogen and Rice, IRRI, Los Baños, 465-484.

[31] Singh, U., Ladha, J.K., Castillo, E.G., Punjalan, G., Tirol-Padre, A. and Duqueza, M. (1998) Genotypic Variation in Nitrogen Use Efficiency in Medium and Long Duration Rice. Field Crops Research, 58, 35-53. http://dx.doi.org/10.1016/S0378-4290(98)00084-7

[32] Craswell, E.T. and Vlek, P.L.G. (1979) Fate of Fertilizer Nitrogen Applied to Wetland Rice. In: Nitrogen and Rice, IRRI, Los Baños, 175-192.

[33] Buresh, R.J., Pampolino, M.F. and Witt, C. (2010) Field-Specific Potassium and Phosphorus Balances and Fertilizer Requirements for Irrigated Rice-Based Cropping Systems. Plant and Soil, 335, 35-64.

http://dx.doi.org/10.1007/s11104-010-0441-z 
Scientific Research Publishing (SCIRP) is one of the largest Open Access journal publishers. It is currently publishing more than 200 open access, online, peer-reviewed journals covering a wide range of academic disciplines. SCIRP serves the worldwide academic communities and contributes to the progress and application of science with its publication.

Other selected journals from SCIRP are listed as below. Submit your manuscript to us via either submit@scirp.org or Online Submission Portal.
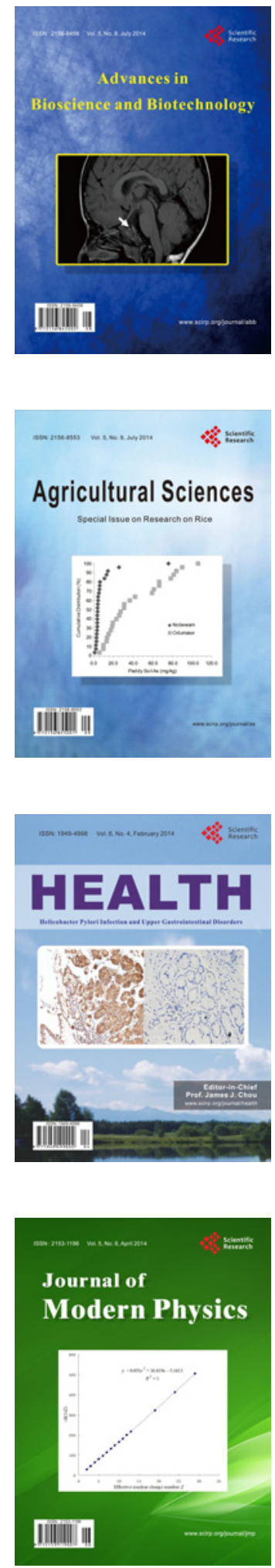
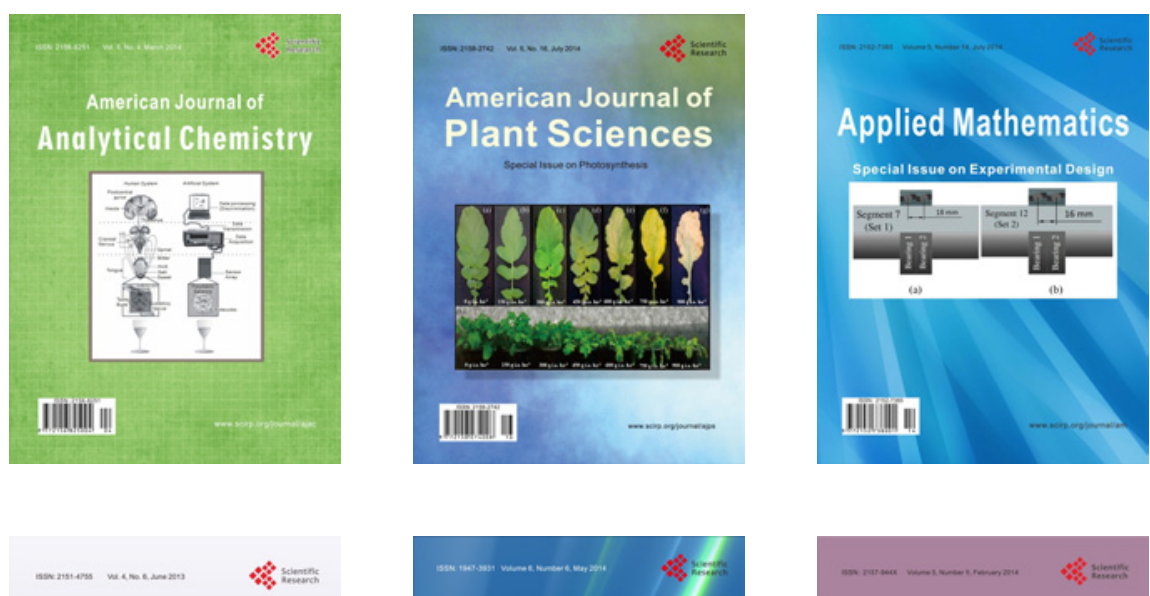

Creative Education
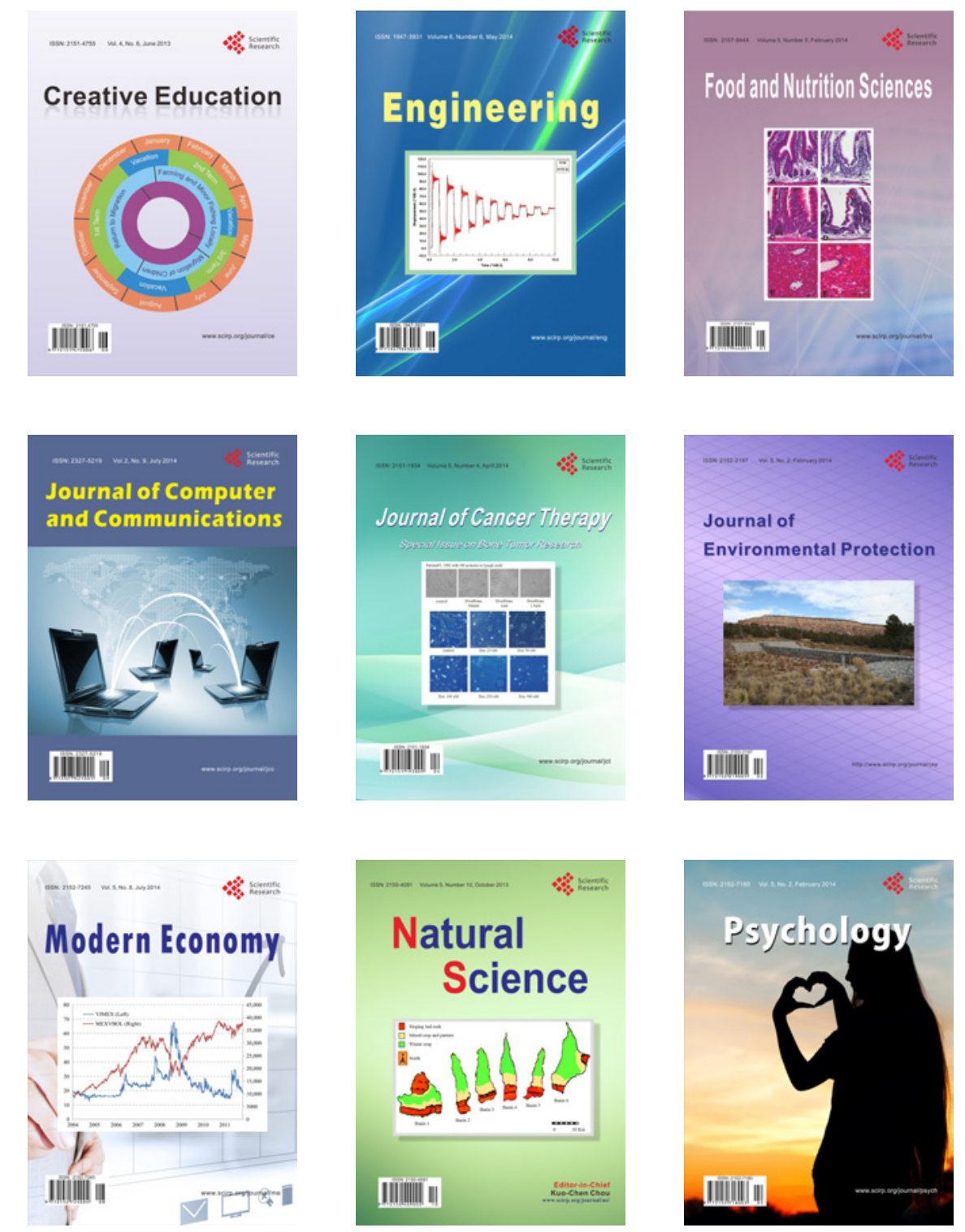